\title{
Attitudes toward Honor and Violence against Women for Honor in the Context of the Concept of Privacy: A Study of Students in the Faculty of Health Sciences
}

\author{
Nurten KAYA $^{1 \oplus}$, Nuray TURAN ${ }^{2 \oplus}$
}

'Prof. Dr., Istanbul University, Health Sciences Faculty, Istanbul, Turkey

${ }^{2} \mathrm{PhD}$ Lecturer, Istanbul University, Florence

Nightingale Nursing Faculty, Istanbul, Turkey

\section{Sorumlu yazar/Corresponding author: Nuray Turan, \\ İstanbul Üniversitesi, Florence Nightingale Hemşirelik Fakültesi, İstanbul, Türkiye \\ E-posta/E-mail: nkaraman@istanbul.edu.tr}

Geliş tarihi/Received: 13.02.2018

Kabul tarihi/Accepted: 24.05.2018

Atıf/Citation: Kaya, N., \& Turan, N. (2018). Attitudes toward honor and violence against women for honor in the context of the concept of privacy: A study of students in the faculty of health sciences. Connectist: Istanbul University Journal of Communication Sciences, 54, 65-84.

https://doi.org/10.26650/CONNECTIST433995

\begin{abstract}
The study was conducted to examine the attitudes of students of health sciences towards violence against women for honor within the context of the concept of privacy and to determine how the attitudes of midwifery students towards honor differ from those of other students. The research design chosen for this study is that of a survey. The subjects of the research consisted of students of health sciences ( $N=952)$, and the sample amounted to 473 students who were selected from this population by stratified random sampling method (departments and classes were taken as stratum criterion). A Student Information Form, the Attitudes towards Honor Scale (AHS), and the Attitudes towards Violence against Women for Protecting Honor Scale (AVWPHS) were used in the data collection. By considering that gender is an important confounding factor in attitudes towards honor, data were presented by dividing subjects into three groups: an all-female group from the midwifery department (MS, $n=97$ ), female students in other departments (FSOD, $n=227$ ), and male students in other departments (MSOD, $n=148$ ). It was observed that there was no difference between MS and FSOD scores for both AHS and AVWPHS. However, MSOD scores were statistically significantly higher than MS and FSOD scores. Although the attitudes of midwifery students in this respect are similar to those of female students in other departments of the faculty, they are different from the attitudes of male students.
\end{abstract}

Keywords: Privacy, honor, violence 


\section{EXTENDED ABSTRACT}

Privacy is an important concept playing a major role in healthcare practices, policies, and law. It has become increasingly common for patients, families, health professionals and institutions to be made aware of health-related privacy policies. In the light of recent studies, it seems that university students studying in the area of health have not studied honesty within the concept of privacy. In this study, one step further, the perspective of the concept of honor between students of health sciences and midwifery students, who are all female, was evaluated.

The study was carried out using a survey in order to determine the attitudes of students of health sciences towards honor and violence against women for honor within the context of the concept of privacy, and to examine whether the attitudes of the Department of Midwifery students were different from those of the students in other departments. The population of the research consisted of the $1^{\text {st }}, 2^{\text {nd }}$ and $3^{\text {rd }}$ grade students studying in a faculty of Health Sciences $(\mathrm{N}=962) .472$ students from this population were included in the study by stratified random sampling method (departments and classes were taken as stratum criteria). The faculty was established in 2010 and began to admit students in 2011; therefore, there were no $4^{\text {th }}$ grade students in the faculty in 2014 when the data of the study were collected. Sampling calculations showed that if the study were conducted with 422 respondents, the error rate would be 0.07 , and the real rate could be reflected by a confidence level of 0.98 . It was predicted that there would be data loss, and 50 students were added to a sample account as a substitution. Thus, it was decided to have a study population of 472 and to use stratified random sampling method. All students in the Department of Midwifery were female. A Student Information Form, the AHS and AVWPHS were used as data collection tools. Before starting the research, informed consent both from the institution and the students was received, in written form from the former and in both verbal and written form from the latter.

The average age for each category of interviewees was 19.92 for midwifery students ( $S D=2.37$ ), 20.18 for female students in other departments $(S D=1.68)$ and 20.84 for male students $(S D=1.55)$, and there was a statistically significant difference between the groups $(p<0.05) .54 .6 \%$ of midwifery students, $57.7 \%$ of female students in other departments and $75 \%$ of male students in other departments said that their families did not interfere in the time they spent outside the home, and there was a 
statistical difference between the groups. This difference was thought to have arisen from the ratio of male students whose time spent outside the home was not interfered with $(p \leq 0.001)$. The ratio of students' extramarital sexual experience was $3.1 \%$ in the Department of Midwifery, $1.3 \%$ in females in other departments and $18.2 \%$ in males in other departments and there was statistical difference between the groups. This difference was thought to have arisen from the fact that the ratio of male students with extramarital sexual experience was much higher than the other groups ( $p<0.001) .15 .5 \%$ of midwifery department students, $15.9 \%$ of female students in other departments and $29.1 \%$ of male students in other departments stated they found extramarital sexual experience acceptable, and there was statistical difference between the groups. This difference was thought to have arisen from the fact that the ratio of male students who found extramarital sexual experience appropriate was much higher than the same ratio in other groups $(p<0.01)$. The students' average scores were obtained from AHS representing their attitudes towards honor and there was statistically significant difference between the groups $(p<0.05)$. As a result of further analysis carried out to determine where the difference between the groups was derived from, it was observed that AHS scores of male students were higher than the scores of the other two groups of female students and that the midwifery department students' scores were similar to the scores of female students in other departments. The students' average scores they obtained from AVWPHS representing their attitudes towards violence against women for honor and there was a statistically significant difference between the groups $(p<0.05)$. As a result of further analysis carried out to determine whence the difference between groups was derived, it was observed that AVWPHS scores of male students were higher than the scores of the other two groups of female students and that the midwifery department students' scores were similar to the scores of female students in other departments.

In conclusion, age, marital status, educational level, the place where a considerable part of life is spent (villages, towns, cities, etc.), family types, and income level, all of which are important elements of cultural and socio-economic status, affect attitudes of and perceptions towards honor. Moreover, gender is the most significant factor in these attitudes and perceptions. 


\section{INTRODUCTION}

The concept of privacy as an issue has been discussed and debated from the past to the present (Diker, 2015). Privacy is defined as a human right, a mechanism of behavior that is employed to create and control the desired limitations on the social interactions of people (Tataroğlu, 2013). With the development of communication technology, social life has radically changed. This causes a significant transformation in society's perceptions of privacy. Social components of culture have a direct impact on the privacy requirements of societies and on the formation of the mechanisms produced to meet such requirements (Zorlu \& Keskin, 2017). In the context of the perception of privacy, the semantics of private honor and chastity are important. Private virtue and chastity sometimes possess the same meaning when used either together or separately (Fettahoğlu, 2016).

The midwife is a reliable and professional health carer with a particular responsibility who graduates from a school providing midwifery training. She provides care for women during pregnancy, birth and post-partum, gives necessary advice, performs the birth according to her own responsibilities, provides care for the newborn child, and works in cooperation with women (Güner, Yurdakul, \& Yetim, 2015; Yıldırım, Koçkanat, \& Duran, 2014). As can be understood from this description, the primary responsibility of the midwife is the woman, and she takes significant responsibility for the protection and development of a woman's health. Therefore, protection of women from being subjected to all kinds of violence for honor, be they physical, psychological, social, cultural, or economic, are among the responsibilities of a midwife. In order for a midwife to be able to perform this important role, it is necessary to determine the viewpoints of midwives on honor and to determine the characteristics of the society in which she works as well.

The concept of honor in Turkey has very different meanings. In the Dictionary of the Turkish Language Society, honor is expressed as "commitment to ethics and social values in a society, chastity, honesty, integrity" (Türk Dil Kurumu, 2010). Uğurlu and Akbaş (2013) stated that the word "chastity" in this definition had meanings such as commitment to ethics in women's sexual behavior, purity and shyness. The concept of 'honor' was discussed with this meaning in the present study. 'Honor' is a concept of high value in Turkey. Behavior that can be discussed as related to a woman's sexuality may include not only sexual intercourse but also a wide variety of behavior such as 
dressing style, holding hands with the opposite sex, requesting a song on the radio for a male, kissing and flirting, bursting into loud laughter blatantly and interrupting the male. In this context, if the behavior of a woman causes damage to her own or her family's honor, she is punished in several ways, and violence for this reason is used in Turkey as well as in many other countries (Doğan, 2014; Işık \& Sakallı-Uğurlu, 2009).

Violence used against women for honor in Turkey is a significant problem, and the concept of custom is an important factor in this problem. In the dictionary of the Turkish Language Association, custom is defined as "the whole of ways of behavior; life, rules, customs and traditions, shared habits;" and "living in certain ways which are adopted and established in a community" (Türk Dil Kurumu, 2010). Deviations from customs usually require harsh and cruel sanctions such as condemnation, exclusion, acts of violence, killing, etc.. (Bilgili \& Vural, 2011).

Honor killing is the most extreme kind of violence used against a woman who is believed to have not protected her honor. According to the Custom and Honor Killings Report (2007) of the Human Rights Presidency of Turkey, 1,148 people were killed for honor between 2003 and 2007. It is probable that this number does not reflect the whole truth, as it is estimated that there are many unregistered killings (Sever \& Yurdakul, 2001). Although honor killings have tried to be prevented legally, they still continue.

There are studies that describe the characteristics that are associated with attitudes about violence for honor in Turkey. It was reported in one of these studies that male students at the university who thought the role of the women was to do housework, give birth to children, and look after the elderly members of the house, and who approved of honor killing, disapproved of their spouses working, and did not believe in the equality of women and men were found to support violence against women by men (Adana et al., 2011). Another study comparing the gender differences in the perception of honor killings showed that Turkish participants attributed more responsibility to the victim and less responsibility to the assailant. Moreover, the Turkish participants proposed less severe punishments than the Italian participants (Caffaro, Ferraris, \& Schmidt, 2014).

Violence against women can be most easily identified in the institution of health care services. A woman is in need of health services for many reasons not related to 
violence. In such cases, the health professional who diagnoses the bio-psycho-sociocultural dimensions of the woman getting healthcare services with violence-related problems can determine the exposure to violence and its causes (Natan, Khater, Ighbariyea, \& Herbet, 2016; Şen, Egelioğlu, Kavlak, \& Sevil, 2012). When the reason for the violence is honor, this situation may be a particular issue for the health professional as well because the health professional is also affected by the culture of the society in which he/she lives. Thus, socio-cultural characteristics of a health professional from a culture of honor may be effective in the perception of honor and violence towards women for honor. Therefore, the perception of health professionals on the issues of honor and violence against women for honor should be examined.

\section{AIM AND METHODOLOGY}

The development of communication technology and its social components has had a direct impact on privacy (Zorlu \& Keskin, 2017). The perception of privacy, and the semantics of private honor and chastity are important. Through addressing the traditional roles in the cultures of honor, different roles and responsibilities of men and women in relation to honor are given. In Turkey, violence used against women for honor is a significant problem in the context of the concept of privacy (Fettahoğlu, 2016). Violence against women can be most easily identified in the institution of health care services. In Turkey, however, it is s not possible to find any relevant study findings about this subject.

\section{Aim}

This research was carried out in order to determine the attitudes of students of health sciences towards honor and violence against women for honor within the context of the concept of privacy, and to examine whether the attitudes of Department of Midwifery students were different from those of students in other departments.

\section{Methodology}

In this study, the research design is survey. This is also called descriptive research. The descriptive research is used to describe the characteristics of a population or phenomenon being studied. 


\section{Questions of the research}

- What are the individual characteristics (age, school year, marital status, mother's and father's educational levels, the place where they spent the longest part of their lives, family type, economic status) of male and female students in the Department of Midwifery and other departments, and are these different from each other?

- What are the features (the status of the interference of the family on the time spent outside the house, the presence of extra-marital sexual experience, the status of finding extramarital sexual experience appropriate) that may affect attitudes of male and female students in the Department of Midwifery and other departments, and are these different from each other?

- What are the scores of the female and male students in the Department of Midwifery and other departments obtained from the Attitudes towards Honor Scale (AHS) and the Attitudes towards Violence against Women for Protecting Honor Scale (AVWPHS), and are they different from each other?

\section{Sampling}

The population of the research consisted of $1^{\text {st }}, 2^{\text {nd }}$ and $3^{\text {rd }}$ grade students studying at a faculty of health sciences ( $N=962) .472$ students from this population were included in the study by stratified random sampling method (departments and classes were taken as stratum criteria). For random sampling, a simple random number table was used. All lists of the classes which belong to $1^{\text {st }}, 2^{\text {nd }}, 3^{\text {rd }}$ grades were obtained. Students were selected using the random number table according to the classes.

The Faculty was established in 2010 and began to admit students in 2011, therefore there were no $4^{\text {th }}$ grade students in the faculty in 2014 , the year in which the data of the study were collected. Sampling calculations showed that if the study had been conducted with 422 respondents, the error rate would be 0.07 , and the real rate could be reflected by a confidence level of $0.98(t ; \infty ; 0.02=2.326)$. It was predicted that there would be data loss, and 50 students were added to the sample account as substitutes. Thus, it was decided to have a study population of 472 and a stratified random sampling method was used. Finally, all students in the Department of Midwifery were female. 


\section{Measurement Instruments}

Data were collected from the completed Student Information Forms, the Attitudes towards Honor Scale (AHS) and the Attitudes towards Violence against Women for Protecting Honor Scale (AVWPHS).

Student Information Form: This form was developed by the researchers. It aimed to gather information on gender, age, department, marital status, mother's and father's educational levels, the place where the student had spent a significant portion of his/her life, family type, economic status, the level of interference of the family in the time spent outside the house, and ideas about and experience in extramarital sexual activity.

Attitudes towards Honor Scale (AHS): The scale, developed by Işık and SakallıUğurlu (2009), consisted of 14 items. Respondents were asked to indicate to what extent they agreed with each item on a 6-point Likert-type scale. The high score in AHS shows that women's honor is associated with virginity, the sexual behaviors of women, the fact that the women are supported by family members, and family honor. Işık and Sakallı-Uğurlu (2009) reported that the Cronbach's alpha of AHS was 0.94. In this study, the Cronbach's alpha of VPS was found to be 0.88 .

\section{Attitudes towards Violence against Women for Protecting Honor Scale} (AVWPHS): This scale, also developed by Işık and Sakallı-Uğurlu (2009), consisted of 14 items. The aim of this scale is to determine the attitudes regarding honor killings as well as attitudes towards verbal and physical violence against women for honor. Respondents were asked to indicate to what extent they agreed with each item on a 6-point Likert-type scale. The high scores obtained from the scale reflect the positive attitude towards violence against women for honor. Işık and Sakallı-Uğurlu (2009) reported that the Cronbach's alpha of AHS was 0.91. In this study, the Cronbach's alpha of VPS was found to be 0.87 .

\section{Ethical Aspect of the Research}

Before starting the research, written informed consent from the institution and verbal and written informed consent from the students was received. Students comprising the sample were informed about the objectives and benefits of the study 
and their roles in it. They were told that they should not write their names on the data collection forms and that they could leave the research at any stage in the process. Their verbal consent was received at the point when they stated their willingness to participate in research and that this was voluntary.

\section{Data Analysis}

Following the oral and written explanation of the study by the researchers, the questionnaire form and the scales were distributed to the students of health sciences who had agreed to volunteer in the project. No names or identifying data were requested. The forms were filled in by the participating students. Data were then evaluated by the researchers.

The collected data were entered into the database in IBM SPSS Statistic 21 program, and all statistical analyses were performed using the same program. Continuous variables were expressed as arithmetic mean, standard deviation, and minimum and maximum values, while categorical variables were expressed as frequency and percentage. Kolmogorov-Smirnov Goodness of Fit Test in a Group was performed for the normality analysis of the data obtained. By determining that the distributions were normal, one-way ANOVA methods were used in determining the difference between the averages of more than two groups, and further analysis was performed with the Tukey HSD method in cases where there was a significant difference. Chisquare tests were used in the analysis of categorical data (Özdamar, 2013).

\section{FINDINGS}

\section{Socio-demographic characteristics of students}

The average age was 19.92 for midwifery students ( $S D=2.37), 20.18$ for female students in other departments ( $S D=1.68)$, and 20.84 for male students ( $S D=1.55)$. There was a statistically significant difference between the groups ( $<<0.05$; Table 1$)$. As a result of further analysis carried out to determine where the difference between groups was derived from, it was observed that the average age of the male students was greater than the average age of the female students from the other two groups, and that the average age of the students in the midwifery department was similar to the average age of the female students of other departments. 
The school year of the students included in the research was the stratum criterion in determining the sample, as it was the variable that might affect the examined honor variable and could possibly be controlled. Thus, no statistically significant difference was observed between the groups according to the variable of school year ( $p>0.05$; Table 1).

When the educational levels of mothers were analyzed, the majority of the Department of Midwifery students' mothers were primary school graduates (46.4\%; $\mathrm{n}=45$ ); the majority of the mothers of female students in other departments were also primary school graduates $(46.3 \% ; n=105)$; and the same was true of the majority of the mothers of male students in other departments $(37.8 \% ; n=56)$. The educational levels of mothers of female students are therefore similar. However, a significant proportion of mothers of male students were not literate, and this difference between male and female students is statistically significant $(p<0.001$; Table 1).

When the students were asked where they spent the greater part of their lives, it was observed that $67.0 \%$ of the midwifery students $(n=65), 58.6 \%$ of female students in other departments $(n=133)$ and $51.4 \%$ of male students in other departments $(n=76)$ gave the answer of "city". It was observed that there was a statistically significant difference between the groups in terms of this variable, and this difference was thought to be caused by the high ratio of the male students' answer of "village" to this question ( $\mathrm{p} \leq 0.01$; Table 1 ).

The nuclear family was the majority family type in all three groups but there was a statistical difference between the groups. This difference between the groups in terms of family type variable arose from the fact that the family type of a significant proportion of male students $(26.4 \% ; n=39)$ was the extended family $(p<0.001$; Table 1$)$.

All students in the department indicated that their economic situation was mostly "my income meets my expenses," but there was a statistical difference between the groups. This difference between the groups in terms of economic situation arose from the fact that the ratio of female students in other departments who stated that their income met their expenses was higher than that of the other two groups ( $p<0.05$; Table 1$)$. 
There was no statistically significant difference between the groups in terms of the marital status of students and the educational levels of students' fathers ( $p>0.05$; Table 1).

\section{Students' characteristics that may affect their attitudes towards honor}

$54.6 \%$ of midwifery department students, $57.7 \%$ of female students in other departments $(n=131)$ and $75 \%$ of male students in other departments $(n=111)$ said that their families did not interfere in the time they spent outside the house, and there was a statistical difference between the groups. This difference was thought to have arisen from the ratio of male students whose time spent outside the house was not in ( $p \leq 0.001$; Table 2$)$.

Turning to the question of students' extramarital sexual experience, $3.1 \%$ of students in the Department of Midwifery $(n=3), 1.3 \%$ of females in other departments $(n=3)$ and $18.2 \%$ of males in other departments $(n=27)$ stated that they had had extramarital sex, and there was a statistical difference between the groups. This difference was thought to have arisen from the fact that the percentage of male students having had an extramarital sexual experience was much higher than that of the other groups $(p<0.001 ;$ Table 2$)$.

$15.5 \%$ of midwifery department students ( $n=15), 15.9 \%$ of female students in other departments $(n=36)$ and $29.1 \%$ of male students in other departments $(n=43)$ stated that they found the experience of extramarital sex acceptable, and there was a statistical difference between the groups. This difference was thought to have arisen from the fact that the ratio of male students who found an extramarital sexual experience to be appropriate was much higher than in the other groups $(p<0.01$; Table 2).

\section{Students' attitudes towards honor and violence against women for honor}

The students' average scores obtained from AHS, representing their attitudes towards honor, showed potential distribution scores of between 1-6, as seen in Table 3 , and there was a statistically significant difference between the groups $(p<0.05)$. As a result of the further analysis carried out to determine where the difference between groups was derived from, it was observed that AHS scores of male students were 
higher than the scores of the groups of female students, and also that the midwifery department students' scores were similar to the scores of female students in other departments.

The students' average scores obtained from AVWPHS representing their attitudes towards violence against women for honor showed potential distribution scores of between 1-6 as seen in Table 3, and there was a statistically significant difference between the groups $(p<0.05)$. As a result of the further analysis carried out to determine where the difference between groups was derived from, it was observed that the AVWPHS scores of male students were higher than the scores of the other two groups and that the midwifery department students' scores were similar to the scores of female students in other departments.

\section{DISCUSSION AND CONCLUSION}

The most important task of women in the culture of honor is to protect their sexual purity, and the most important indicator of sexual purity in Turkey is virginity. In Turkey, women are expected not to engage in sexual intercourse until they get married (Bilgili \& Vural, 2011; Gürsoy \& Özkan, 2014; Sakallı, Karakurt, \& Uğurlu, 2001). When honor is perceived to be tainted, individuals may feel negative emotions such as shame, anger and humiliation, and they may exhibit different behavior in order to correct or repair these negative emotions. An example of negative behavior in relation to honor is that the shameful act may be kept confidential and within the family. The woman, who is considered to have damaged her honor, may be verbally warned, reprimanded or physically punished. This physical punishment may extend to beating and killing (Öztürk \& Demirdağ, 2013; Uğurlu \& Akbaş, 2013).

The perception of honor is affected by various factors such as people's social gender, age, place of residence where they spend their lives, education, and tribal and kinship relations. In particular, honor is seen as something very important and the loss of it can lead the person concerned being killed. It serves as the meaning and purpose of life for people from rural origins who have strong tribal and kinship relations, and for whom the family and community have an exalted place in their lives, and whose environments are not changed even if they migrate to the city (Inci, 2013). 
On the other hand, a patriarchal sexist mentality still exerts influence in many societies. This understanding is conveyed to new generations in their socialization process and is reproduced again and again. People who grow up and become socialized with this understanding think that discrimination between male and female children, using violence against women, women working for low wages, and excluding women from the workplace will not lead to any change in their status and will not increase their right to speak in the family. In order to overcome this vicious circle and to eliminate the spiral of violence in society, the influence of this patriarchal sexist mentality in society should be decreased (Can, 2013).

In the study carried out by Eisner and Ghuneim (2013), attitudes towards honor crimes among teenagers were investigated. The study found that killing a sister, daughter or wife who had dishonored the family could be justified by nearly $40 \%$ of boys and $20 \%$ of girls. A systematic analysis of the research literature about honor killings in the Middle East and North Africa (MENA) was carried out by Kulczycki and Windle (2011). A paucity of studies in relation to the presumed magnitude of the problem was indicated by the study. As stated in this study, the victims are particularly young females who are murdered by a male. Forty case files taken from Arabic- and Kurdish-speaking clients of a London nongovernmental organization (NGO) providing services to women who were exposed to violence were examined by Payton (2014). In their experiences of violence, along with ramifications for service provisions, interrelationships were observed between 'honor', agnation, and collectivity.

In conclusion, age, marital status, educational level, the place where a considerable part of life is spent (villages, towns, cities, etc.), family types, and income level are important elements of cultural and socio-economic status and affect attitudes and perceptions of honor. Gender is the most important confounding factor in attitudes and perceptions towards honor (Can, 2013; Gursoy, McCool, Sahinoglu, \& Yavuz Genc, 2014; İnci, 2013; Öztürk \& Demirdağ, 2013; Sakallı-Uğurlu \& Ulu, 2003; Yılmaz et al., 2009). Therefore, in this study, data were categorized in consideration of the variable of gender while examining the attitudes of midwifery students towards the issue. However, except for the variables of marital status and education levels of fathers, significant differences were observed among the students of the midwifery department and the students from other departments in the other variables examined. Therefore, the groups compared in terms of the variables that can affect 
the perception of honor in particular should be similar enough to be able to say that the perceptions of honor of students in the midwifery department are different from those of students in other departments. This issue is an important limitation of the present study.

Furthermore, the educational level of the students' mothers is an important matter that should be taken into consideration as a factor which increases the limitation of the study. In this study, the educational level of female students' mothers was observed to be similar while a significant proportion of male students' mothers were observed to be illiterate. Gürsoy \& Özkan (2014) stated that students' attitudes towards the perception of honor for women became more equitable as the educational levels of mother and father increased; in particular, the mother's educational level is the most important factor affecting students' attitudes. Zeyneloğlu, Kısaoğlu, and Yılmaz (2013) observed that students' attitudes towards social gender roles became more positive and equitable as the mother's educational level increased. This shows that both preventing violence and ensuring gender equality may be possible through the education of women.

In addition, the results of a study carried out in Turkey (TC Başbakanlık Insan Hakları Başkanlığı, 2007) showed that the number of perpetrators and victims of custom and honor killings increased as the educational level decreased; that not only women but also men could be aggrieved in custom and honor killings; that those who committed murder, or defendants, were mostly in the 19-35 age range; and that the increase of unreasonable penalties relating to custom and honor killings does not produce a deterrent effect on those who commit or will commit these crimes.

In this study, the status of the interference of the family on the time spent outside the house, extramarital sexual experience and the status of finding extramarital sexual experience appropriate were issues that were examined in consideration of the fact that they would be confounding factors in students' perception of honor. The results obtained were observed to be similar to other studies carried out in Turkey. Sakallı-Uğurlu \& Glick (2003) reported that male students in particular said that they did not find premarital sexual intercourse of women appropriate. Gürsoy \& Özkan (2014) reported that the traditional attitude of male students about honor was most clearly observed in the dimension of premarital sex and the sense of honor, which is the third sub-dimension of the scale they used. Vefikuluçay, Zeyneloğlu, Eroğlu, and 
Taşkin (2007), in their study carried out with final-year university students, stated that $79 \%$ of male students and $49 \%$ of female students agreed that "the woman who would marry a man must be absolutely virgin". Yılmaz et al. (2009) stated in their studies that $83 \%$ of male students and $30 \%$ of female students agreed with the same statement. Moreover, it was determined that male respondents were not very interested in marriage with a girl who was not a virgin. Gürsoy \& Vural (2003) and Zeyneloğlu et al. (2013) stated that nursing students and nurses supported the idea that the woman should be a virgin when she gets married. On the other hand, despite the gender difference in the responses to the question of honor, it is seen in studies that, at present and to a significant extent, a woman's honor is evaluated traditionally and is associated with her sexuality.

Gursoy et al. (2014) examined scores of attitudes of students towards the understanding of honor for women according to gender, and observed that the attitudes of male students were more traditional or negative compared with those of female students. Also, in the present study, attitudes of midwifery students towards honor are similar to those expressed in other studies carried out in Turkey, and they are not different from those of female students studying in other departments. Therefore, midwifery students' perceptions of honor reflect the overall perception of honor among women in Turkey. Although this perception is more common among men, there are women who consider honor as corresponding to women's sexuality and the man as the guardian of that honor. On the other hand, male students' perceptions of honor in this study are similar to the perceptions of honor among males living in a patriarchal social structure. This result of the study is similar to those in other studies carried out in Turkey but different from female students in school.

This research was conducted at only one school of health sciences in Turkey. Thus, the results can only pertain to the students at that school and cannot be generalized across all health schools. It is suggested that similar studies to the present study could be conducted in different health schools both nationally and internationally.

\section{REFERENCES}

Adana, F., Arslantaş, H., Ergin, F., Biçer, N., Kıranşal, N., \& Şahin, S. (2011). Views of male university students about social gender roles; An example from east of Turkey. Journal of Family Violence, 26(7), 519-526. 
TC Başbakanlık İnsan Hakları Başkanlığı. (2007). Töre ve namus cinayetleri raporu [The custom and honor killings report]. Retrieved from http://www.kamer.org.tr/eng/content_images/tore_namus_cinayetleri_raporu_ 02_07_2008.pdf.

Bilgili, N., \& Vural, G. (2011). Kadina yönelik şiddetin en ağır biçimi: Namus cinayetleri [The heaviest way of violence against women: Honor killings]. Journal of Anatolia Nursing and Health Sciences, 14(1), 66-72.

Caffaro, F., Ferraris, F., \& Schmidt, S. (2014). Gender differences in the perception of honour killing in individualist versus collectivistic cultures: Comparison between Italy and Turkey. Sex Roles, 71(9-10), 296-318.

Can, Y. (2013). Kadına yönelik şiddetin toplumsal cinsiyet temelleri: Niğde örneği [Gendered bases of violence against woman: Niğde case]. Zeitschrift für die Welt der Türken/Journal of World of Turks, 5(1), 203-216.

Diker, E. (2015). The understanding of woman and privacy in newspaper advertisements. Gumushane University E-Journal of Faculty of Communication, 3(1), 95-110.

Doğan, R. (2014). The profiles of victims, perpetrators, and unfounded beliefs in honor killings in Turkey. Homicide Studies, 23, 1-28.

Eisner, M., \& Ghuneim, L. (2013). Honor killing attitudes amongst adolescents in Amman, Jordan. Aggressive Behavior, 39(5), 405-417.

Fettahoğlu, S. (2016). The semantic of private, unrelated, virtue andpudicity concepts and their usage in Koran. International Periodical for the Languages, Literature and History of Turkish or Turkic, 11(5), 269-284.

Gursoy, E., McCool, W. F., Sahinoglu, S., \& Yavuz Genc, Y. (2014). Views of women's sexuality and violence against women in Turkey: A cross-sectional investigation among university students. Journal of Transcultural Nursing, 15, 1-10.

Güner, S., Yurdakul, M., \& Yetim, N. (2015). Türkiye'de ebelik mesleğinin sorunlarına akademik bakışı yansıtan nitel bir çalışma [A qualitative study on the academic approach to the professionalization of midwifery in Turkey]. Journal of Higher Education and Science, 5(1), 80-87.

Gürsoy, E., \& Özkan, H. A. (2014). Türkiye'de üniversite öğrencilerinin kadına ilişkin “namus” algısı [Turkish youth's perception of sexuality / "honor" in relation to women]. Journal of Psychiatric Nursing, 5(3), 149-159.

Işık, R., \& Sakallı-Uğurlu, N. (2009). Namusa ve namus adına kadına uygulanan şiddete ilişkin tutumlar ölçeklerinin öğrenci örneklemiyle geliştirilmesi [The development of attitudes toward honor scale and attitudes toward violence against women for protecting honor scale with a student sample]. Turkish Psychological Articles, 12(24), 16-24.

İnci, Ü. H. (2013). Basında yer alan namus cinayetlerinin sosyolojik analizi [A sociological analysis of honor killings reported by the mass media]. Journal of History Culture and Art Research, 2(3), 282-296.

Kim, Y. H., \& Cohen, D. (2010). Information, perspective, and judgments about the self in face and dignity cultures. Personality and Social Psychology Bulletin, 36(4), 537-550.

Kulczycki, A., \& Windle, S. (2011). Honor killings in the Middle East and North Africa: A systematic review of the literature. Violence Against Women, 17(11), 1442-1464. 
Leung, A. K.Y., \& Cohen, D. (2011). Within-and between-culture variation: Individual differences and the cultural logics of honor, face, and dignity cultures. Journal of Personality and Social Psychology, 100(3), 507-526.

Natan, M. B., Khater, M., Ighbariyea, R., \& Herbet, H. (2016). Readiness of nursing students to screen women for domestic violence. Nurse Education Today, 44, 98-102.

Özdamar, K. (2013). Paket programlar ile istatiksel veri analizi II (9th ed.) [Package programs and statistical data analysis II]. Eskişehir, Turkey: Nisan Kitabevi.

Öztürk, M., \& Demirdağ, A. G. (2013). Namusunu kanla temizleyenler: Mardin Cezaevi'nde namus davası nedeniyle yatan mahkûmlar üzerine bir araştırma [The ones who restored his honour with blood: $A$ sociological research on the prisoners convicted of honour issue in Mardin jailhouse]. Journal of Social Policy Studies, 7(30), 16-35.

Payton, J. (2014). "Honor," collectivity, and agnation: Emerging risk factors in "honor"-based violence. Journal of Interpersonel Violence, 29(16), 2863-2883.

Sakallı Uğurlu, N., \& Glick, P. (2003). Ambivalent sexism and attitudes toward women who engage in premarital sex in Turkey. Journal of Sex Research, 40(3), 296-302.

Sakallı Uğurlu, N., \& Ulu, S. (2003). Evlilikte kadına yönelik şiddete ilişkin tutumlar: Çelişik duygulu cinsiyetçilik, yaş, eğitim ve gelir düzeyinin etkileri [Attitudes toward violence against women in marriage: The effects of ambivalent sexism, age, education and income levels]. Turkish Psychological Articles, 6, 53-65.

Sakallı, N., Karakurt, G., \& Uğurlu, O. (2001). Evlilik öncesi yaşanan cinsel ilişkiye ve kadınlarin evlilik öncesi cinsel ilişkide bulunmasına karşı tutumlar [Attitudes toward sexual relationship and females' sexual experiences before marriage]. Istanbul University Studies in Psychology, 22, 15-29.

Sever, A., \& Yurdakul, G. (2001). Culture of honor, culture of change a feminist analysis of honor killings in rural Turkey. Violence Against Women, 7(9), 964-998.

Şen, S., Egelioğlu, N., Kavlak, O., \& Sevil, Ü. (2012). Sağlık profesyonellerinin gebelikte şiddet konusundaki farkındalıklarının belirlenmesi [Determination of awareness of health professionals about violence during pregnancy]. International Journal of Human Sciences, 9(1), 20-33.

Tataroğlu, M. (2013). Privacy İmpact Analysis (PIA) in preventing privacy issues. Management and Economics, 20(1), 263-289.

Türk Dil Kurumu. (2010). Büyük Türkçe sözlük [Great Turkish dictionary]. Ankara, Turkey: Author.

Uğurlu, N. S., \& Akbaş, G. (2013). Namus kültürlerinde "namus" ve "namus adına kadına şiddet": Sosyal psikolojik açıklamalar ["Honor" and "honor violence against women" in honor cultures: Social psychological explanations]. Turkish Psychological Articles, 16(32), 92-94.

Vefikuluçay, A. G. D., Zeyneloğlu, A. G. S., Eroğlu, K., \& Taşkin, L. (2007). Kafkas Üniversitesi son sınıf öğrencilerinin toplumsal cinsiyet rollerine ilişkin bakış açıları [Perception of and views on gender roles of senior students enrolled at Kafkas University]. Journal of Hacettepe University Faculty of Nursing, 14(2), 26-38.

Yıldırım, G., Koçkanat, P., \& Duran, Ö. (2014). Ulusal ebelik kodlari ve meslek değerleri [National codes of midwifery and professional values]. Sürekli Tıp Eğitim Dergisi, 23(4), 148-154. 
Yılmaz, D. V., Zeyneloğlu, S., Kocaöz, S., Kısa, S., Taşkın, L., \& Eroğlu, K. (2009). Üniversite öğrencilerinin toplumsal cinsiyet rollerine ilişkin görüşleri [Views on gender roles of university students]. International Journal of Human Sciences, 6(1), 775-792.

Zeyneloğlu, S., Kısa, S., \& Yılmaz, D., (2013). Turkish nursing students' knowledge and perceptions regarding virginity. Nurse Education Today, 33(2), 110-115.

Zorlu, T., \& Keskin, K. (2017). The phenomenon of privacy in the culture-dwelling interaction: A comparative analysis over traditional Urfa and Akçaabat ortamahalle houses. Online Journal of Art and Design, 5(2), 7289. 


\section{TABLES}

Table 1: Distribution of socio-demographic characteristics by gender of students ( $\mathrm{N}=472)$

\begin{tabular}{|c|c|c|c|c|}
\hline $\begin{array}{l}\text { Socio- demographic } \\
\text { characteristics }\end{array}$ & $\begin{array}{r}\text { Department of } \\
\text { midwifery } \\
\begin{array}{r}\text { (a) }(\mathbf{n}=97) \\
n(\%)\end{array}\end{array}$ & $\begin{array}{r}\text { Female students } \\
\text { of other } \\
\text { departments (b) } \\
(n=227) \\
n(\%)\end{array}$ & $\begin{array}{r}\text { Male students of } \\
\text { other departments } \\
\text { (c) }(n=148) \\
n(\%)\end{array}$ & $\begin{array}{r}\chi^{2 / F} \\
p\end{array}$ \\
\hline Age (Min-Maks.) & $(17-40)$ & $(18-36)$ & $(18-29)$ & $F=9.236$ \\
\hline Mean $\pm S D$ & $19.92 \pm 2.37$ & $20.18 \pm 1.68$ & $20.84 \pm 1.55$ & $\begin{array}{r}p=0.000 / \\
c>a=b\end{array}$ \\
\hline \multicolumn{5}{|l|}{ Year at school } \\
\hline $1^{\text {st }}$ year & $48(49.5)$ & $78(34.4)$ & $49(33.1)$ & \multirow{3}{*}{$\begin{aligned} \chi 2 & =8.370 \\
p & =0.079\end{aligned}$} \\
\hline $2^{\text {nd }}$ year & $25(25.8)$ & $75(33.0)$ & $47(31.8)$ & \\
\hline $3^{\text {th }}$ year & $24(24.7)$ & $74(32.6)$ & $52(35.1)$ & \\
\hline \multicolumn{5}{|l|}{ Marital status } \\
\hline Married & $2(2.1)$ & $3(1.3)$ & $1(0.7)$ & \multirow{2}{*}{$\begin{aligned} \chi 2 & =0.906 \\
p & =0.636\end{aligned}$} \\
\hline Single & $95(97.9)$ & $224(98.7)$ & $147(99.3)$ & \\
\hline \multicolumn{5}{|l|}{ Mother's educational level } \\
\hline Illiterate & $10(10.3)$ & $17(7.5)$ & $30(20.3)$ & \multirow{6}{*}{$\begin{array}{r}\chi 2=38.265 \\
p=0.000\end{array}$} \\
\hline Literate & $6(6.2)$ & $8(3.5)$ & $17(11.5)$ & \\
\hline Primary school graduates & $45(46.4)$ & $105(46.3)$ & $56(37.8)$ & \\
\hline Secondary school graduates & $15(15.5)$ & $25(11.0)$ & $19(12.8)$ & \\
\hline High school graduates & $20(20.6)$ & $48(21.1)$ & $16(10.8)$ & \\
\hline $\begin{array}{l}\text { Associate degree/ } \\
\text { baccalaureate or higher } \\
\text { graduates }\end{array}$ & $1(1.0)$ & $24(10.6)$ & $10(6.8)$ & \\
\hline \multicolumn{5}{|l|}{ Father's educational level } \\
\hline Illiterate & $1(1.0)$ & $4(1.8)$ & $6(4.1)$ & \multirow{6}{*}{$\begin{array}{r}\chi 2=14.048 \\
p=0.171\end{array}$} \\
\hline Literate & $4(4.1)$ & $6(2.6)$ & $7(4.7)$ & \\
\hline Primary school graduates & $37(38.1)$ & $67(29.5)$ & $51(34.5)$ & \\
\hline Secondary school graduates & $21(21.6)$ & $41(18.1)$ & $24(16.2)$ & \\
\hline High school graduates & $24(24.7)$ & $58(25.6)$ & $28(18.9)$ & \\
\hline $\begin{array}{l}\text { Associate degree/ } \\
\text { baccalaureate or higher } \\
\text { graduates }\end{array}$ & $10(10.3)$ & $51(22.5)$ & $32(21.6)$ & \\
\hline \multicolumn{5}{|l|}{ Longest place of residence } \\
\hline Village & $2(2.1)$ & $19(8.4)$ & $19(12.8)$ & \multirow{4}{*}{$\begin{array}{r}\chi 2=16.470 \\
p=0.011\end{array}$} \\
\hline Small town & $6(6.2)$ & $4(1.8)$ & $8(5.4)$ & \\
\hline Town & $24(24.7)$ & $71(31.3)$ & $45(30.4)$ & \\
\hline City & $65(67.0)$ & $133(58.6)$ & $76(51.4)$ & \\
\hline \multicolumn{5}{|l|}{ Family type } \\
\hline Nuclear family & $87(89.7)$ & $197(86.8)$ & $107(72.3)$ & \multirow{3}{*}{$\begin{array}{r}\chi 2=23.720 \\
p=0.000\end{array}$} \\
\hline Extended family & $7(7.2)$ & $24(10.6)$ & $39(26.4)$ & \\
\hline Broken families & $3(3.1)$ & $6(2.6)$ & $2(1.4)$ & \\
\hline \multicolumn{5}{|c|}{ Does their economic income meet their expenses? } \\
\hline Yes & $69(71.1)$ & 185 (81.5) & $105(70.9)$ & $\chi 2=7.105$ \\
\hline No & $28(28.9)$ & $42(18.5)$ & $43(29.1)$ & $p=0.029$ \\
\hline
\end{tabular}


Table 2: Distribution of characteristics that may affect their attitudes towards honor by gender of students $(\mathrm{N}=\mathbf{4 7 2})$

\begin{tabular}{|c|c|c|c|c|}
\hline $\begin{array}{l}\text { The characteristics } \\
\text { that may affect their } \\
\text { attitudes }\end{array}$ & $\begin{array}{r}\text { Department } \\
\text { of midwifery } \\
(n=97) \\
n(\%)\end{array}$ & $\begin{array}{r}\text { Female students of } \\
\text { other departments } \\
\left(\begin{array}{r}n=227) \\
n(\%)\end{array}\right.\end{array}$ & $\begin{array}{r}\text { Male students of } \\
\text { other departments } \\
(n=148) \\
n(\%)\end{array}$ & $\begin{array}{r}\chi^{2} \\
p\end{array}$ \\
\hline \multicolumn{5}{|c|}{ The families' intervene status in time they spent outside } \\
\hline Yes & $44(45.4)$ & $96(42.3)$ & $37(25.0)$ & $\chi 2=14.647$ \\
\hline No & $53(54.6)$ & $131(57.7)$ & $111(75.0)$ & $p=0.001$ \\
\hline \multicolumn{5}{|c|}{ Extramarital sexual experience } \\
\hline Yes & $3(3.1)$ & $3(1.3)$ & $27(18.2)$ & $\chi 2=42.304$ \\
\hline No & $94(96.9)$ & $224(98.7)$ & $121(81.8)$ & $p=0.000$ \\
\hline \multicolumn{5}{|c|}{ Extramarital sexual experience appropriate found status } \\
\hline Yes & $15(15.5)$ & $36(15.9)$ & $43(29.1)$ & $\chi 2=11.297$ \\
\hline No & $82(84.5)$ & $190(84.1)$ & 105 (70.9) & $p=0.004$ \\
\hline
\end{tabular}

Table 3: Distribution of Attitudes toward Honor Scale and Attitudes toward Violence against Women for Protecting Honor Scale scores by gender of students

\begin{tabular}{|c|c|c|c|c|c|c|c|}
\hline \multirow[t]{2}{*}{ Scales } & \multicolumn{2}{|c|}{$\begin{array}{l}\text { Department of } \\
\text { midwifery } \\
\text { (a) }(n=97)\end{array}$} & \multicolumn{2}{|c|}{$\begin{array}{c}\text { Female students of } \\
\text { other departments }(b) \\
(\mathbf{n}=227)\end{array}$} & \multicolumn{2}{|c|}{$\begin{array}{c}\text { Male students of } \\
\text { other departments (c) } \\
(n=148)\end{array}$} & \multirow[t]{2}{*}{$\begin{array}{l}\mathbf{F} \\
\mathbf{p}\end{array}$} \\
\hline & Min.-Maks. & Mean \pm SD & Min.-Maks. & Mean \pm SD & Min.-Maks. & Mean \pm SD & \\
\hline AHS* & $1.00-4.67$ & $2.58 \pm 0.93$ & $1.00-5.13$ & $2.54 \pm 0.95$ & $1.00-5.80$ & $3.48 \pm 1.04$ & $\begin{array}{l}F=45.761 \\
p=0.000 \\
c>a=b\end{array}$ \\
\hline AVWPHS ** & $1.00-3.50$ & $1.56 \pm 0.63$ & $1.00-3.64$ & $1.67 \pm 0.74$ & $1.00-5.79$ & $2.40 \pm 1.01$ & $\begin{array}{l}F=45.014 \\
p=0.000 \\
c>a=b\end{array}$ \\
\hline
\end{tabular}

* Attitudes toward Honor Scale

** Attitudes toward Violence against Women for Protecting Honor Scale 